\title{
Ant diversity under three coverages in a Neotropical coffee landscape
}

\author{
Rocío García-Cárdenas ${ }^{1}$, James Montoya-Lerma² \& Inge Armbrecht ${ }^{2}$ \\ 1. Department of Biology, University of Quindío, Colombia. Programa de Biología, Universidad del Quindío, Colombia; \\ rociogarcia@uniquindio.edu.co \\ 2. Department of Biology, University of Valle, Colombia. Departamento de Biología. Universidad del Valle, Colombia; \\ james.montoya@correounivalle.edu.co, inge.armbrecht@correounivalle.edu.co
}

Received 15-II-2017. Corrected 17-VII-2018. Accepted 16-VIII-2018.

\begin{abstract}
The coffee cultivation has displaced natural vegetation and its associated biological diversity. The present study describes the diversity of ground-dwelling ants on eight plantations where coffee is grown in the shade (SHD), eight plantations where coffee is grown under unshaded coffee (SUN) and four patches of forest (FOS) in a coffee-growing region of Colombia. The research was conducted in transects composed of 12 sampling stations, each of which employed active collection, pitfall traps and litter sifting. Nine habitat variables were analyzed to characterize each site, and these values were related to the diversity of ants and functional groups. A total of 92 morphospecies were collected. Myrmicinae was the subfamily with the highest representation. The sample coverage presented a deficit of less than $5 \%$. The rank abundance curves exhibited differences in the ant assemblages. The ant communities found in the forest exhibited greater diversity and a larger number of exclusive species than the communities found in locations of other land uses; the SHD and SUN communities were characterized by $80.3 \%$ and $62.3 \%$, respectively, of the diversity found in the forest communities. The functional similarity index as adapted for guilds by Sørensen reveals a high degree of similarity in the structure of their ant communities, but less so in their composition. The shaded coffee plantations have a richer and more equitable ant fauna than the exposed coffee plantations, reinforcing the idea that shade cultivation favors the establishment of ant fauna and, consequently, ecological functionality.
\end{abstract}

Key words: plantation agroecosystems; associated diversity; ants; coffee growing; Colombia.

García-Cárdenas, R., Montoya-Lerma, J. \& Armbrecht, I. (2018). Ant diversity under three coverages in a Neotropical coffee landscape. Revista de Biología Tropical, 66(4), 1373-1389.

The conversion of land to coffee cultivation and the intensification of coffee production are among the major causes of changes in natural vegetation and other soil cover types in tropical areas (Perfecto \& Vandermeer, 2002; Perfecto \& Armbrecht, 2003; Guhl 2004; Jha et al., 2014). Crops such as coffee, occupy large areas at moderate elevations of the tropics, and their cultivation has led to a drastic reduction in biodiversity (Perfecto \& Vandermeer, 2015). In Colombia, it is estimated that $70 \%$ or more of the original extent of the Andean forest has been transformed (Etter \& van Wyngaarden, 2000), largely as the result of the expansion of coffee cultivation. In 2010, Colombian coffee plantations accounted for approximately 3000000 hectares in 19 departments, along the slopes of the Andes between 1000 and 2000 meters above sea level (Federación Nacional de Cafeteros FNC, 2010), and $60 \%$ of the land dedicated to the cultivation of this crop has experienced a reduction in shade cover and the application of chemical inputs such as pesticides and herbicides, among others (Guhl, 2004).

Although technology inputs yield greater production, the land is subjected to an accentuated process of intensification that results in 
soil degradation (Perfecto, Rice, Greenberg, \& Van der Voort., 1996). Characteristics such as spatial heterogeneity or the degree of homogenization in agricultural landscapes, as well as management practices, can affect the diversity and distribution of local and regional biota, as well as the incidence of invasive species or pests (Armbrecht, Rivera, \& Perfecto, 2005; Philpott et al., 2008). Because of technological advances, quantitative information is now available, and a compendium of images portrays the size, speed and extent of the patterns of deforestation; however, little is yet understood about the effect of fauna reduction on the functions and services of ecosystems (Dirzo et al., 2014).

Research on coffee ecosystems has received considerable attention in recent decades, particularly due to the effects that the intensification of coffee production has had on the associated biodiversity (Perfecto \& Vandermeer, 2015). Studies of ants, in particular, have proved useful in analyzing diversity and conservation in these agro-ecosystems. For example, it has been documented that the diversity of ants may be reduced in monoculture coffee plantations under full sun conditions due to changes in light and leaf litter (Perfecto \& Vandermeer, 2002; Armbrecht et al., 2005) as well as a reduction of nesting sites for several species (Philpott \& Foster, 2005; Roberts et al., 2000). In this regard, the quality of the microhabitat's structure is a determining factor for the establishment of many species of ants; this is the case for traditional crops of shade-grown coffee, which contain a greater diversity of ants because they ensure the minimal requirements for the survival of ant communities (Armbrecht $\&$ Perfecto, 2003). The negative impacts of full-sun plantations on guilds of predatory and omnivorous ground-dwelling ants has also been studied (García, Zabala, \& Botero, 2008; Dias et al., 2013), emphasizing the role of this group of insects within the different habitats in predicting the ant communities' response to disturbances (Andersen, 1997; Leal, Wirth, \& Tabarelli, 2014).

Several studies in Colombia have associated the diversity of ant populations with the management of coffee plantations, especially in the area known as the coffee zone (Armbrecht et al., 2005; Rivera \& Armbrecht, 2005; Gallego-Ropero, 2005, García et al., 2008; Zabala, Arango, \& de Ulloa, 2013). Nevertheless, the country's geographical location, its topography and different life stories provide great diversity in the structure and composition of communities, and the ecological context often affects the manner in which ants respond to changes in land use. This is especially true for Colombian coffee plantations, where rapid transformation has favored the establishment of plantations at higher altitudes and displaced the majority of production towards the southern part of the country (FNC, 2011). There are few studies that relate the diversity of ant populations to the management of coffee plantations in these areas (Urrutia-Escobar \& Armbrecht, 2013). The present study describes the specific diversity of ground-dwelling ants and identifies functional groups in two contrasting coffee-cultivation systems (shaded and exposed) and a control system (forest patches) in the department of Cauca, in the southwestern Colombian Andes.

\section{MATERIALS AND METHODS}

Study site: The study was conducted in the municipalities of Popayán and Cajibío, located in the department of Cauca, in the Southwestern Colombian Andes, at an altitudinal strip between 1450 and 1800 meters above sea level; defined by Holdridge (Espinal, 1968) as premontane moist forest (bh-PM). The climate is temperate and humid, with a mean temperature of $27.9^{\circ} \mathrm{C}$; the region experiences a bimodal rainfall regime with a mean annual precipitation of $2258 \mathrm{~mm}$. The region is characterized by mixed coffee cultivation in small plots that has areas of exposed coffee monoculture and heterogeneous growth, including both exposed and shaded coffee plantations. Between May and September 2014, 20 research sites were chosen for the study, including eight shaded coffee plantations, eight unshaded coffeeplantations and four forest patches (Fig. 1). 


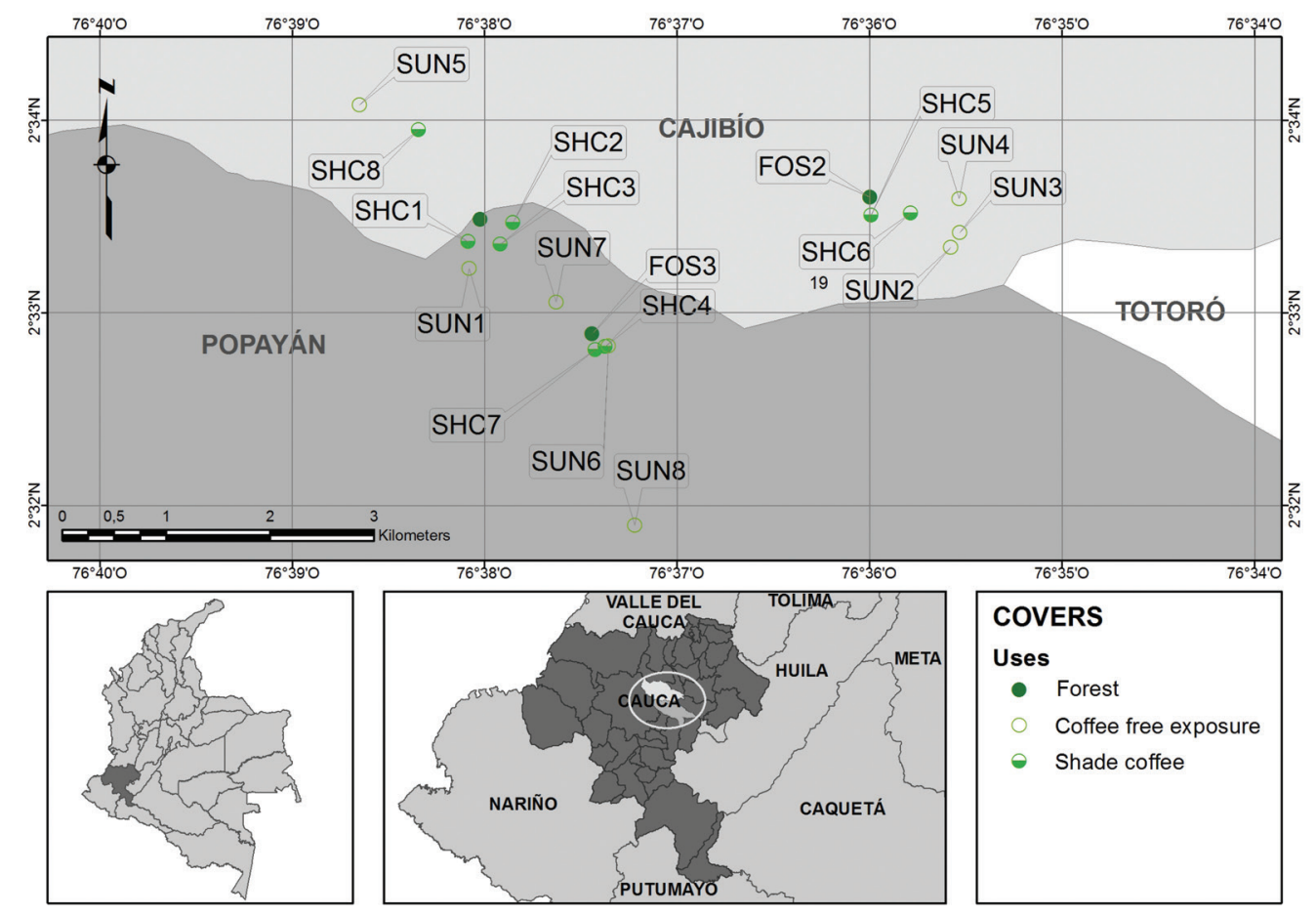

Fig. 1. Study area in the department of Cauca, Southwestern Colombia.

Ant sampling: In general, the sampling protocol suggested by Alonso and Agosti (2000) was followed. Each site was demarcated by two transects 50 meters long and two meters wide, with 12 sampling points established at ten-meter intervals. An active search was conducted at each station for 20 minutes, followed by the placement of a pitfall trap with $95 \%$ ethyl alcohol for $24 \mathrm{~h}$. In addition, the entire layer of leaf litter from a $1-\mathrm{m}^{2}$ area was collected and sifted using the mini-Winkler extraction technique for $48 \mathrm{~h}$. A total of 36 samples were obtained from each site. The collected samples, preserved in $90 \%$ alcohol, were initially separated by morphospecies. Subsequently, were organized at the lowest possible taxonomic level using Fernández (2003) generic keys and various specific keys according to genus. Comparisons were also made with material classified by specialists from a collection stored in the Museum of Entomology of the Universidad del Valle, Cali (MUSENUV, national registry of collections 077 ). The specimens, duly mounted on pins, labeled and classified, are preserved in the museum's collection (Jiménez et al., 2016).

Habitat variables: In each study site, two separate sampling points at least $50 \mathrm{~m}$ from each other were chosen at random. At each point, a circle $24 \mathrm{~m}$ in diameter was drawn and bisected by two axes: one in a north-south orientation, the other in an east-west orientation. At points located every four meters along these axes, measurements were taken and analyzed for nine habitat variables distributed over three vertical levels (Armbrecht, 2003): 1) the arboreal level: canopy cover, tree richness, tree density, epiphytic richness, tree height and tree diameter; 2) coffee plant level: coffee plant density and mean coffee plant height; and 3) soil level: leaf litter depth.

Functional groups: The species were classified into functional groups based on the literature (Delabie, Agosti, \& Nascimento, 
2000; Silvestre, Brandão, \& Da Silva, 2003; Silva \& Brandão, 2010; García-Martínez et al., 2015). The classification of these groups allows a functional comparison of the ants to be made at the different intensity levels of the study sites (forest patches, exposed coffee plantations and shaded coffee plantations) using the Sørensen similarity index, adapted by Silvestre (2000), which includes the number of guilds at each sample point and the number of species present within the guilds. In cases where information is not reported or the specific epithet is not known, the classification is based on habits reported for the genus.

Data analysis: We used Hill's numbers to analyze diversity, measured in units of effective number of species (Jost, 2006): ${ }^{0} \mathrm{D}$ (species richness), ${ }^{1} \mathrm{D}$ (exponential of the Shannon index) and ${ }^{2} \mathrm{D}$ (inverse of the Simpson index). These measures comply with the principle of replication, are easy to interpret and are therefore recommended in comparative studies of diversity (Jost, 2010; Chao et al., 2014). The completeness of the sample was measured considering the sample coverage (Cs) at the management level and among different types of plantations and forest patches (sites). This measure makes it possible to compare the diversity of communities among samples of the same coverage, using extrapolation and interpolation of the coverage of their reference samples (Chao \& Jost, 2012; Chao et al., 2014), with the subroutine $\mathrm{R}$ for data on frequency of capture, where 0 represents the minimum and 100 the maximum completeness (R Development Core Team, 2014). A visual comparison of the confidence intervals was performed to establish significant differences (no overlap) between land uses or management (Cumming Fidler, \& Vaux, 2007), and analysis of variance and ANOVA post hoc comparisons were performed after confirming the normality of the data. The Jaccard similarity index was used to compare the composition of species between land use types. This index has values ranging from 0 (minimum similarity) to 100 (maximum similarity) and was represented using the un-weighted pair group method with an arithmetic mean (UPGMA). The statistical robustness of this result was based on the similarity profile test (SIMPROF), using the PRIMER software, version 6.1.16 (Clarke \& Gorley, 2006). The relationship between the composition of species and sites, explained by environmental variables, was established through a canonical correlation analysis (CCA) and generalized linear models in accordance with the distribution of the data and the type of variable using the R-3.2.1 software (R Development Core Team, 2014).

\section{RESULTS}

Overview: A total of 15666 individuals from nine subfamilies were collected, distributed over 40 genera and 92 morphospecies (Table 1). Sixty percent of the individuals were identified to the species level. The remaining $40 \%$ belonged to genera with difficult taxonomic identification such as Pheidole, Solenopsis, Hypoponera and Camponotus (Lyal \& Weitzman, 2004). Myrmicinae accounted for the largest representation in the samples (44 species), followed by Dolichoderinae (six species) and Ponerinae (13 species). Pheidole was the genus with the largest number of species (14), followed by Solenopsis (8) and Strumigenys (7). The most abundant species (in individuals) were Solenopsis sp. 1 (2871), Linepithema piliferum (2231), Solenopsis sp. 2 (1692) and Wasmannia auropunctata (1 617).

The samples collected from the shaded coffee plantations (SHD) contained a greater number of species (61 species and 5672 individuals), whereas those collected from the unshaded coffees (SUN) contained a greater number of individuals (7 813) but fewer species (48). In contrast, the forest patches (forests) had 56 species represented by only a few individuals (2 181); this coverage was also remarkable for containing the highest number of exclusive species (21), including Adelomyrmex tristani, Apterostigma goniodes, Cyphomyrmex salvini, Discothyrea horni, Gnamptogenys bisulca, Gnamptogenys nigrivitrea, Neoponera 
TABLE 1

List of the ant species found in each soil use. FOS: forests, SHC: coffee with shade and SUN: unshaded coffee

\begin{tabular}{|c|c|c|c|c|}
\hline Species & FOS & SUN & $\mathrm{SHC}$ & Total \\
\hline Adelomyrmex tristani & 3 & & & 3 \\
\hline Apterostigma gonoides & 4 & & & 4 \\
\hline Atta cephalotes & 114 & 182 & 8 & 304 \\
\hline Azteca velox rochai & & & 2 & 2 \\
\hline Brachymyrmex heeri & 11 & 6 & 4 & 21 \\
\hline Brachymyrmex longicornis & 20 & 79 & 118 & 217 \\
\hline Camponotus sp. 2 & & 2 & 22 & 24 \\
\hline Camponotus sp. 4 & & 1 & & 1 \\
\hline Camponotus sp. 7 & & 1 & 8 & 9 \\
\hline Camponotus sp. 9 & & 1 & 1 & 2 \\
\hline Cardiocondyla minutior & & 33 & & 33 \\
\hline Cheliomyrmex andicola & & 39 & 11 & 50 \\
\hline Crematogaster crinosa & 12 & & 17 & 29 \\
\hline Crematogaster nigropilosa & 3 & & 28 & 31 \\
\hline Cyphomyrmex cornutus & 17 & 66 & & 83 \\
\hline Cyphomyrmex rimosus & 228 & 84 & 7 & 319 \\
\hline Cyphomyrmex salvini & 11 & & & 11 \\
\hline Discothyrea horni & 1 & & 1 & 2 \\
\hline Dorymyrmex biconis & & 12 & & 12 \\
\hline Ectatomma ruidum & & 84 & 17 & 99 \\
\hline Gnamptogenys andina & & & 15 & 15 \\
\hline Gnamptogenys bisulca & 55 & & & 55 \\
\hline Gnamptogenys dichotoma & & & 1 & 1 \\
\hline Gnamptogenys nigrivitrea & 22 & & & 22 \\
\hline Heteroponera microps & 15 & 27 & 19 & 61 \\
\hline Hypoponera sp. 1 & 8 & 7 & 11 & 26 \\
\hline Hyроропеra sp. 2 & & 69 & 20 & 89 \\
\hline Hyроропеra sp. 3 & 5 & 46 & 22 & 73 \\
\hline Hyроропеra sp. 4 & 7 & 4 & 34 & 45 \\
\hline Hypoponera sp. 5 & 1 & & 2 & 3 \\
\hline Labidus coecus & 13 & 1 & & 14 \\
\hline Labidus praedator & & & 31 & 31 \\
\hline Leptogenys pucuna & 1 & & & 1 \\
\hline Linepithema fuscum & & 164 & 63 & 227 \\
\hline Linepithema iniquium & 4 & 61 & 25 & 90 \\
\hline Linepithema neotropicum & & 75 & 171 & 246 \\
\hline Linepithema piliferum & 95 & 1075 & 1061 & 2231 \\
\hline Mayaponera constricta & 2 & & & 2 \\
\hline Myrmelachista zeledoni & 2 & 1 & & 3 \\
\hline Neivamyrmex punctaticeps & & & 27 & 27 \\
\hline Neoponera aenescens & 9 & & & 9 \\
\hline Neoponera verenae & 14 & & 6 & 20 \\
\hline Nesomyrmex asper & 1 & & 45 & 46 \\
\hline Nylanderia steinheili & 84 & & & 84 \\
\hline Octostruma balzani & & 2 & 7 & 9 \\
\hline Octostruma stenoscapa & 3 & & & 3 \\
\hline
\end{tabular}


TABLE 1 (Continued)

\begin{tabular}{|c|c|c|c|c|}
\hline Species & FOS & SUN & $\mathrm{SHC}$ & Total \\
\hline Odontomachus chelifer & 1 & 104 & 44 & 149 \\
\hline Odontomachus eritrocephalus & & & 48 & 48 \\
\hline Pachycondyla fuscoatra & 1 & & & 1 \\
\hline Pheidole sp. 1 & 1 & 1063 & 161 & 1225 \\
\hline Pheidole sp. 11 & 45 & & 1 & 46 \\
\hline Pheidole sp. 12 & 61 & & & 61 \\
\hline Pheidole sp. 13 & 73 & 3 & 3 & 79 \\
\hline Pheidole sp. 14 & 2 & & & 2 \\
\hline Pheidole sp. 15 & 16 & 3 & 82 & 101 \\
\hline Pheidole sp. 16 & 85 & & & 85 \\
\hline Pheidole sp. 21 & 14 & & 22 & 36 \\
\hline Pheidole sp. 22 & 1 & & & 1 \\
\hline Pheidole sp. 3 & 25 & & & 25 \\
\hline Pheidole sp. 4 & 2 & 1179 & 931 & 2112 \\
\hline Pheidole sp. 5 & & 1 & 3 & 4 \\
\hline Pheidole sp. 6 & & 132 & 31 & 163 \\
\hline Pheidole sp. 7 & 59 & & 37 & 96 \\
\hline Prionopelta amabilis & & 1 & 20 & 21 \\
\hline Pseudomyrmex ejectus & & & 1 & 1 \\
\hline Pseudomyrmex gracilis gracilis & & & 1 & 1 \\
\hline Pseudomyrmex sp. 3 & & & 1 & 1 \\
\hline Pseudomyrmex sp. 4 & & 1 & & 1 \\
\hline Pseudomyrmex sp. 5 & & 5 & & 5 \\
\hline Pseudomyrmex sp. 7 & & 1 & & 1 \\
\hline Rasopone ferruginea & 43 & 1 & 6 & 50 \\
\hline Rhopalothrix sp. 1 & 5 & & & 5 \\
\hline Rogeria belti & 5 & 1 & 1 & 7 \\
\hline Solenopsis geminata & & & 38 & 38 \\
\hline Solenopsis sp. 1 & 30 & 2288 & 553 & 2871 \\
\hline Solenopsis sp. 2 & 768 & 535 & 389 & 1692 \\
\hline Solenopsis sp. 3 & & 87 & 2 & 89 \\
\hline Solenopsis sp. 4 & & & 2 & 2 \\
\hline Solenopsis sp. 6 & 34 & 4 & 25 & 63 \\
\hline Solenopsis sp. 7 & & 90 & 5 & 95 \\
\hline Solenopsis sp. 8 & & & 16 & 16 \\
\hline Stigmatomma orizabanum & 3 & & & 3 \\
\hline Strumigenys connectens & 3 & & & 3 \\
\hline Strumigenys denticulata & 11 & 15 & & 26 \\
\hline Strumigenys louisianae & & 14 & 1 & 15 \\
\hline Strumigenys margaritae & & & 3 & 3 \\
\hline Strumigenys nubila & 71 & & 4 & 75 \\
\hline Strumigenys raptans & 20 & & & 20 \\
\hline Strumigenys skia & & 16 & 2 & 18 \\
\hline Typhlomyrmex pusillus & 2 & & & 2 \\
\hline Wasmannia auropunctata & 35 & 147 & 1435 & 1617 \\
\hline TOTAL & 2181 & 7767 & 5672 & 15666 \\
\hline
\end{tabular}


aenescens, Stigmatomma orizabanum, Strumigenys raptans and Typhlomyrmex pusillus.

Sample coverage and diversity: The sample coverage at the land use level exhibited a deficit of less than $5 \%$ (range 95.8-97.7\%); therefore, to compare the diversity of species in their different orders $\left({ }^{9} \mathrm{D}\right)$, the sample was interpolated to $95.8 \%$ completeness with a confidence interval (CI) of $95 \%$. The total results for each type of land use reveal a zeroorder difference in diversity (species richness) between sites with canopy cover (forests and SHD) and sites exposed to direct sun (SUN), with very similar values for SHD and forests (Fig. 2). The other levels of diversity $\left({ }^{1} \mathrm{D}\right.$ and $\left.{ }^{2} \mathrm{D}\right)$ exhibited significantly higher diversity in the forests than in the two coffee plantations. The diversity of common species $\left({ }^{1} \mathrm{D}\right)$ presented significant differences between shaded and exposed coffee plantations, but the diversity of dominant species $\left({ }^{2} \mathrm{D}\right)$ exhibited no difference between SHD and SUN.

A comparison of the zero-order diversity among all the sites representing each land use (Fig. 3) reveals a higher mean value for the forest sites but no significant differences among the three types of land use $(\mathrm{F}=$ 1.81, $\mathrm{P}<0.1931)$. The ${ }^{1} \mathrm{D}$ diversity exhibited

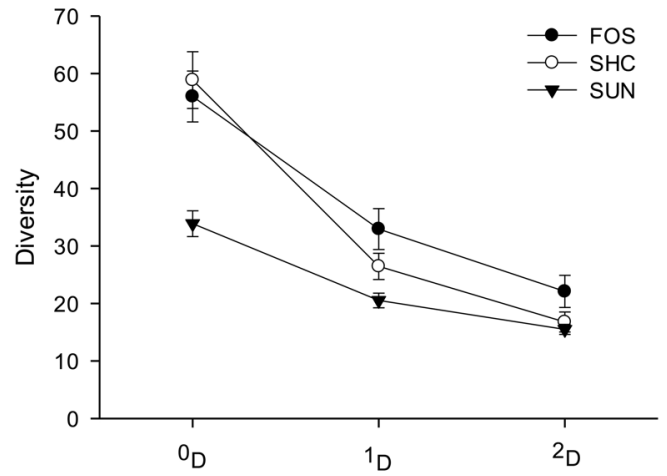

Fig. 2. Comparison of the three orders of diversity of soil ants in the three soil uses (FOS: forest patches, SHC: shade coffee and SUN: unshaded coffee). ${ }^{0} \mathrm{D}$ : richness, ${ }^{1} \mathrm{D}$ : typical diversity, ${ }^{2} \mathrm{D}$ : Diversity of the most abundant species.

differences between management types ( $\mathrm{F}=$ $4.58, \mathrm{P}<0.025)$, and the Tukey test indicated that the forest and SUN sites were significantly different $(\mathrm{t}=-3.25, \mathrm{P}<0.0196)$. The diversity of dominant species also exhibited variation among management systems $(\mathrm{F}=3.7174, \mathrm{P}<$ $0.025)$, and the Tukey test indicated that this difference occurred between forest and SUN sites $(\mathrm{t}=-2.578, \mathrm{P}<0.048)$. These results reveal a large variability within each land use type, and by some measures of diversity,
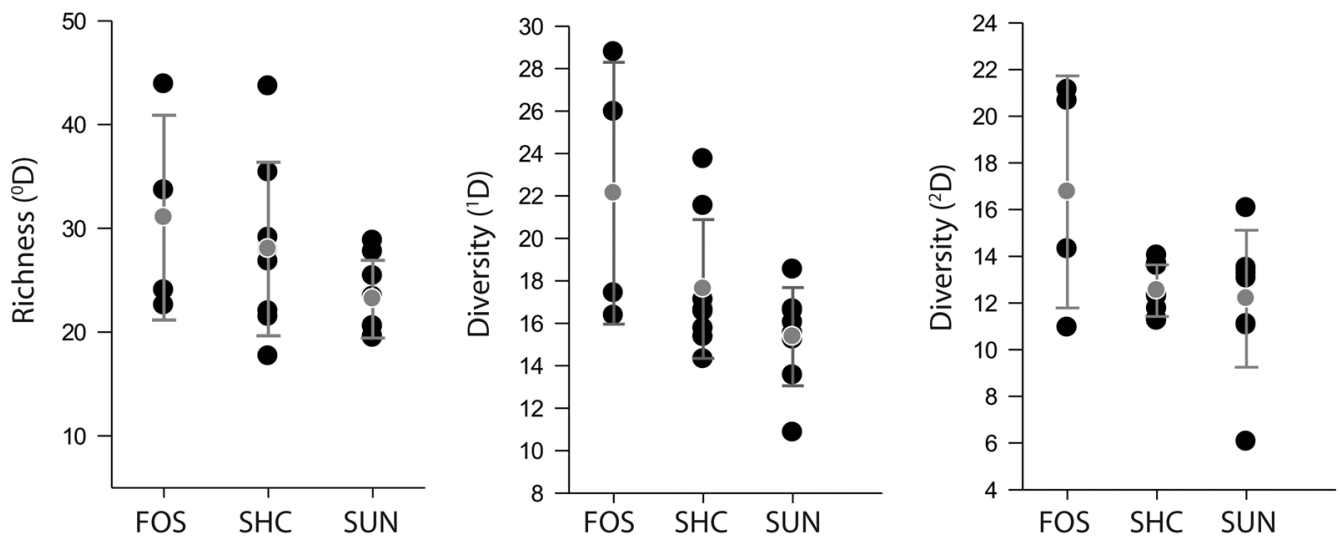

Soil usage

Fig. 3. Local diversity $(\alpha)$ of ants at sites grouped by soil use. The gray dots represent the mean and bars $95 \%$ confidence intervals. FOS: forests, SHC: coffee with shade and SUN: unshaded coffee. 
the SHD sites resemble forests, while others resemble the SUN sites.

\section{Composition of species among differ-} ent land use types: The Whittaker curves present species distribution according to their abundance (frequency of capture) at sites with different land use types (Fig. 4). The curves with steeper slopes appear in the areas planted with coffee, especially in SUN, due to the presence of few species in great abundance. However, the forest sites also indicate the dominance of two species, Solenopsis sp. 2 and Cyphomyrmex rimosus, but the slope is more gradual towards the center of the curve, with a second group led by Atta cephalotes, which is distributed more equitably. Finally, the curve is tapering at those rare species with low frequency of capture. In the SHD sites, Wasmannia auropunctata was found to be the dominant species, whereas Solenopsis sp. 1 was dominant in the SUN sites. The abundance of L. piliferum and Pheidole sp. 4 is notable in both coffee plantation types.

A graphical and statistical comparison of the composition of ants among different sites (Fig. 5) reveals that at a low level of similarity $(12.4 \%)$, there is a significant separation $(\pi=18.64, \mathrm{P}<0.05)$ between the group of forested sites (FOR3, FOR1, FOR4, FOR2), together with three shaded coffee plantations (SHD3, SHD1, SHD2), and the remaining sites. At $23 \%$ similarity, there is a significant separation between the forests and SHD3, SHD1 and SHD2 $(\pi=2.81, \mathrm{P}<0.05)$. At 33.6 $\%$ similarity, there is significant separation between the sun-grown coffee site 8 (SUN8) and the other SUN sites $(\pi=10.94, \mathrm{P}<0.05)$. At $53 \%$ similarity, the sun-grown coffee site 4 (SUN4) is separated from the other SUN sites $(\pi=7.96, \mathrm{P}<0.05)$ and at $64.9 \%$ similarity, it is apparent that the shaded coffee plantations constitute a significantly separate group from the exposed coffee plantations $(\pi=6.9, \mathrm{P}<$ 0.05 ), but shaded coffee site 8 exhibits no differences from the exposed coffee plantations.

Relationship between diversity and environmental variables: Environmental variables explain $81.34 \%$ of the variability of species composition. Most of this variability was explained by axis $1(28.6 \%)$ and axis $2(16.7$ $\%$ ). All of the unshaded coffee (SUN) and five of the eight shaded coffee plantations (SHD) exhibit high values for soil and air temperature variables and for coffee plant density. The other

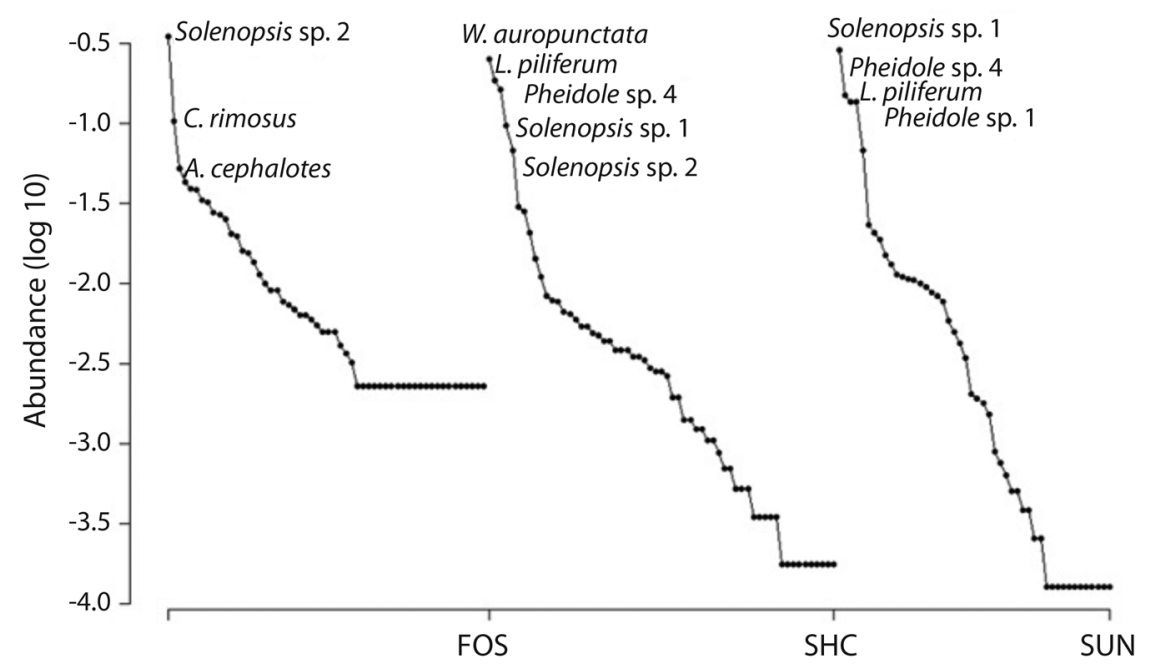

Fig. 4. Relative abundance curves for ant species in three contrasting soil usage. FOS: forests, SHC: coffee with shade and SUN: unshaded coffee. 


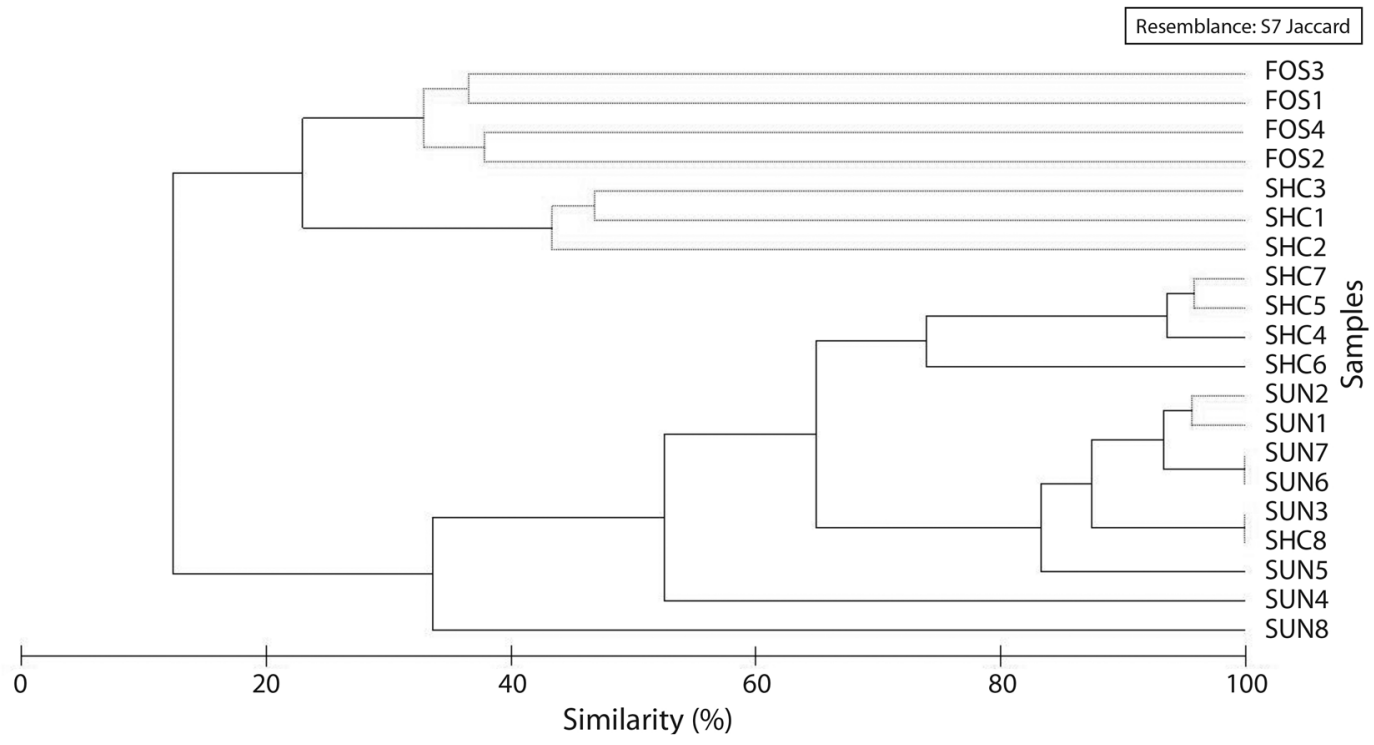

Fig. 5. Ant assemble associated to the different soil uses in the Cauca coffee area, based on Jaccard similarity index. Continuous lines show statistically different groups according to SIMPROF, while dotted lines the groups not statistically separated by SIMPROF. FOS: forests, SHC: coffee with shade and SUN: unshaded coffee.

variables had higher values in the forest, especially relative humidity and the density of trees and epiphytes (Fig. 6).

Functional groups: Ten functional groups of ants were found: nine in forests, ten in unshaded coffee plantations and nine in shaded coffee plantations. In general, the dominant guild of omnivorous ground-dwelling ants accounted for the greatest number of species (22), followed by the group of specialized predatory cryptic poneromorphs (15 species) and specialized predatory cryptic Myrmicinae (14 species); these were the most commonly found guilds in the three land use types. The first group consists predominantly of Pheidole and Solenopsis, which nest in the ground and are aggressive, wide-ranging foragers that are generalists in their eating habits. The second group includes the small poneromorphs, which, like the third guild, nest at ground level or in leaf litter. Their presence is thus associated with the amount of leaf litter, which explains why they are found in greater numbers in the forest. Guilds of Pseudomyrmecinae and minimal vegetation specialists appeared infrequently in the sample, because the method used was aimed at the soil's myrmecofauna. Moreover, the nomadic habit of legionnaire ants makes it difficult to find them in the field; these three groups were therefore excluded from the analysis of functional similarity.

The functional similarity index as adapted for guilds by Sørensen reveals greater similarity between the shaded and exposed coffee plantations (71.58 \%), as these land uses share 37 species in seven guilds, indicating a high degree of similarity in the structure of their ant communities, but less so in their composition. Therefore, ecological equivalence is considered present in several of these species. One of the guilds that best represents this is the guild of large predatory species, where species such as Neoponera verenae and Odontomachus erythrocephalus complement the predatory role in soils of shaded coffee plantations; in contrast, Ectatomma ruidum and Odontomachus chelifer are most abundant in soils of exposed coffee plantations. The other comparisons exhibit values approximately at or below $50 \%$ for 


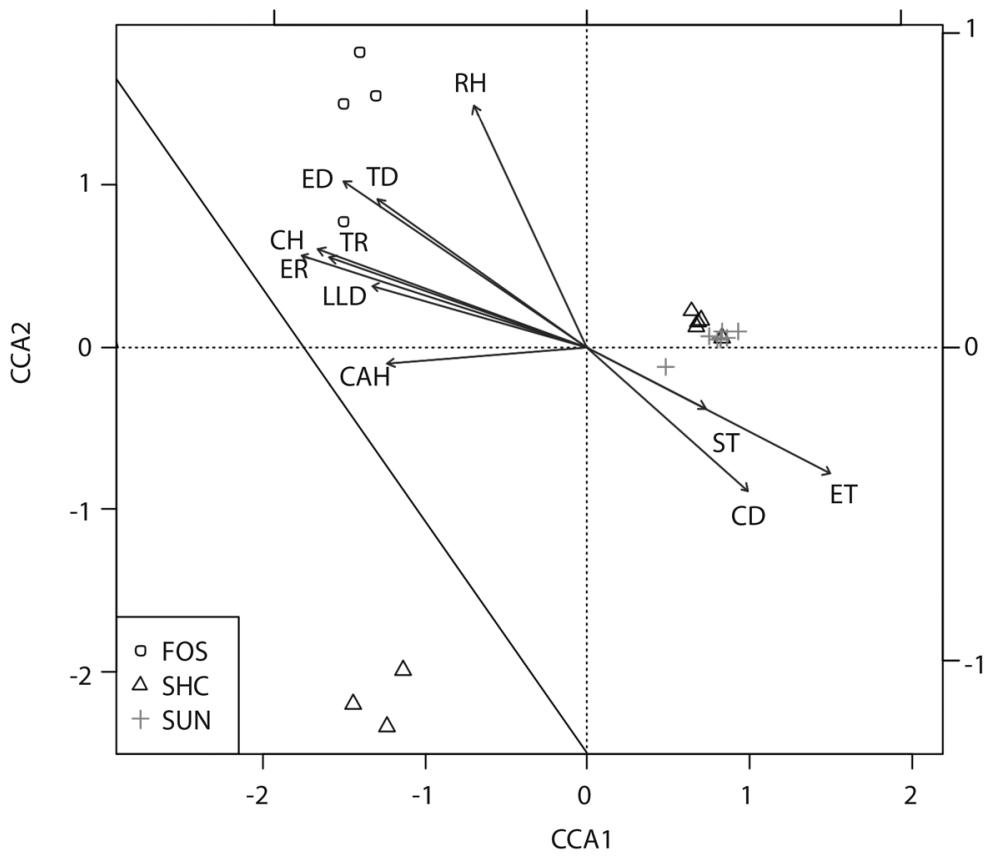

Fig. 6. Canonical correspondence analysis. $\mathrm{CH}$ : coffee height, $\mathrm{CAH}$ : canopy height, CC: Canopy cover, TD: tree density, CD: coffee density, ED: epiphyte density, LLD: leaf litter depth, RH: relative humidity, TR: tree richness, ER: epiphyte richness, ST: soil temperature ET: environmental temperature.

similarity among ant communities. Forests and shaded coffee plantations exhibit $54 \%$ similarity; these two land use types share 29 species in seven guilds. Forests and unshaded coffee plantations exhibit a similarity index of 42.11 $\%$, sharing 20 species in seven guilds.

\section{DISCUSSION}

The use of complementary methods such as leaf litter extraction with Winkler bags, pitfall traps and manual collection, as suggested by Alonso and Agosti (2000), ensured a high sampling coverage (range 95.8 - 97.7\%) for a megadiverse family such as Formicidae. These methods have been used in several studies in Colombia, yielding very good results in heterogeneous landscapes (Jiménez, Lozano-Zambrano, \& Álvarez-Saa, 2008; García, Zabala, \& Botero, 2008).

The species richness of ants recorded for the area (92 morphospecies) is similar to that found by other authors in other coffee-growing areas of Andean Colombia. Including vegetation ants, Armbrecht et al. (2005), documented 115 morphospecies in Apía (Risaralda) and 65 morphospecies in Támesis (Antioquia), two locations of the central Andes. Using tuna bait, Gallego and Armbrecht (2005) reported 54 species of ants in coffee plantations in the former region. Applying a method similar to the one used in this study to three 2500-ha sites, Sánchez-Clavijo, Durán, Vélez, García, and Botero (2008) reported 75 species in El Cairo (Valle del Cauca), 110 in Támesis (Antioquia) and 99 in Santander. Zabala et al. (2013) recorded 96 species of ants in the leaf litter of three representative samples of a coffee-growing landscape in the western Andes of Risaralda. Using Winkler sacs, Cepeda-Valencia, Pérez -Pedraza, L., and Fernández (2014) documented 96 morphospecies of ants associated with leaf litter in both forest patches and shaded coffee plantations in Cundinamarca. Based on this 
evidence, ant assemblages in coffee-growing areas of the Colombian Andes tend to fluctuate at approximately 100 species.

In the department of Cauca, the closest reports to the research site are those by Sinisterra Gallego-Ropero, and Armbrecht (2016), who identified a community of ants present in extrafloral nectaries of guamo trees (Inga edulis and I. densiflora) used for shade on coffee plantations and the myrmecofauna in the leaf litter on the ground; these authors reported 43 species of ants. In an area of Cauca located approximately $60 \mathrm{~km}$ North of the present research site, Urrutia-Escobar and Armbrecht (2013) reported 82 species of ants in the coffee farms of Caldono, Cauca, with the greatest species richness found in shaded coffee plantations (60), followed by forest patches (56) and finally the exposed coffee plantations (33 species). It is noteworthy that the composition of ants in the two aforementioned landscapes differs by 34 species from the results recorded in the present study, including several species of Strumigenys and Gnamptogenys. These agricultural ecosystems seem to be composed of significant ant fauna, considering that Fernández and Sendoya (2004) reported 700 species in Colombia.

The total number of species counted in the SHD sample was three species more than in the forest patches, but the latter contain the most exclusive species (21), with a smaller representation of total area in the region. However, the use of an effective number of species makes it possible to draw direct comparisons of the magnitude of the difference among communities (Jost, 2007; 2010), and the use of a fixed percentage of sample coverage makes it possible to adjust for the number of samples without losing information; this provides greater certainty to the finding that forests have more diverse ant communities than do other land use types. This difference suggests that forests have, on average, 1.25 and 1.6 times more diversity of ants than do SHD and SUN, respectively. In other words, SHD maintains $80.3 \%$ and SUN $62.3 \%$ of the diversity of these forests. Clearly, the SUN sites represent environments with the fewest number of species, differing statistically from other land uses, possibly due to factors related to the intensification of coffee cultivation. It is possible that the mechanisms that explain this difference are both physiological and ecological in nature, as reported by Philpott and Armbrecht (2006).

Our results are consistent with other studies in which forest patches, even when significantly disturbed, function as a reservoir of species or sometimes as a connector between cultivated areas and native forests (Zabala et al., 2013). Similarly, shaded coffee plantations can function as a favorable environment for ant fauna (Philpott, Perfecto, \& Vandermeer, 2006; Perfecto \& Vandermeer, 2015). Armbrecht, Rivera \& Perfecto (2005) and Urrutia-Escobar and Armbrecht (2013) revealed a reduction of ant species richness associated with the intensification of coffee cultivation. García et al. (2008) also reported greater diversity of ants in areas with greater vegetation cover, such as forest patches and shaded coffee plantations, and a reduction of this diversity in exposed coffee plantations.

The composition of species found in our study partially coincides with records of other coffee-growing areas of the country, as well as expanding the distribution of several species in the department of Cauca. The composition of ant species in the region's forests differed significantly from the majority of the coffee plantations, especially those that lacked shade. In fact, the exposed coffee plantation displayed notable differences in both composition and diversity from habitats that contain trees (forests and shaded coffee plantations). The biological value of forests is especially noteworthy for the species found exclusively in forested patches, such as A. tristani, A. goniodes, Fulakora orizabana, S. raptans, S. nubila, S. connectens and T. pusillus, among others; the presence of these species indicates that, although they have been significantly disturbed and not protected by any means, these small patches of forest still preserve fauna typical of native forest ecosystems. As in other studies, in the Colombian coffee zone, shaded coffee plantations have a richer and more equitable 
ant fauna than unshaded coffee plantations, reinforcing the idea that implementation of shade favors the establishment of ant fauna.

The rank abundance curves were constructed based on the frequency of capture along the sampling points, attempting to reduce the effect of these social insects' foraging type. The species' distribution according to their abundance varied for the three types of land use, i.e., each land use presented a different species as being most abundant; this is the result of differences in the structure of communities, in part a result of history, land use and the requirements of the species. It is interesting to note that $C$. rimosus is one of the dominant species in the soil of the forest patches. This species, which cultivates fungi, is characterized by small nests and prefers open, damp areas (Mehdiabadi \& Schultz, 2010); however, this species was not abundant in areas of other land use types, possibly because the moisture and type of leaf litter in forest soils favored the species, whereas some agronomic practices in planted areas may have hindered the species' establishment. Conversely, species such as $L$. piliferum and Pheidole sp. 4, which are generalists, were very abundant in coffee plantations but rare in forest patches. It is worth noting that $L$. piliferum has been reported to care for root aphids such as Aleyrodidae and Pseudococcidae (Wild, 2007), a relationship that has been reported in Colombia by Mera-Velasco, Gallego-Ropero, and Armbrecht, (2010) and by Ramirez, Herrera, and Armbrecht (2010) in the departments of Cauca and Valle del Cauca, respectively. This situation needs to be investigated in greater detail, given that several nests of this ant species were observed to contain aphids among the roots of coffee plants, especially in the exposed coffee sites.

The analysis of similarity based on the composition of species reinforces the aforementioned finding: the ant fauna found in forest patches differs from that found in coffee plantations, sharing only $12.4 \%$ of its species with exposed coffee plantations. This is in part because 22 species found in SUN were not found in the forest patches, whereas the latter displayed 21 exclusive species. The shaded coffee plantations occupy an intermediate position between forest patches and SUN sites, with some SHD sites conveying greater resemblance to forest patches in their species composition, whereas others more closely resemble SUN sites. These results signify the importance of preserving the few remaining forest fragments embedded in the agricultural matrices, especially because they are not protected by conservation measures. Ideally, these forest patches will function as a source of species and proper shade management practices in coffee plantations will contribute to an increase of associated diversity in coffee production areas.

The classification of ants by functional groups or guilds and knowledge about the functionality and importance of ants in soil-related processes has been shown to facilitate a predictive understanding of how ant communities respond to disturbances (Silvestre et al., 2003). The fact that ten different groups were observed indicates the versatility of roles played by these ants in coffee farming systems. The dominant group of omnivorous ground-dwelling ants displayed the highest species richness, which is explained by the presence of the genera Pheidole and Solenopsis. The former is widely distributed globally, classified as hyperdiverse and one of the most common genera in the Neotropics, with approximately 500 species (Wilson, 2003); Solenopsis is also described as very common in leaf litter, with more than 90 species in the Neotropics (Fernández, 2003). These genera have been reported in farming systems of several countries (Pacheco, Vasconcelos, Groc, Camacho, \& Frizzo; Saad, SouzaCampana, Bueno, \& Morini, 2017; Perfecto \& Vandermeer, 2015), and some of their species have been indicated as potential predators of the coffee berry borer (Hypothenemus hampei Ferrari) (Gallego \& Armbrecht, 2005; Philpott \& Armbrecht, 2006).

A comparison of guilds between the different land uses also reflects greater similarity between forest patches and shaded coffee plantations, but an analysis of the composition of species reveals marked differences among 
some groups. The large ground-dwelling predators are most affected. Only two of the eight species reported in this study were found with high frequency in the SUN sites: $O$. chelifer (104 records) and E. ruidum (84 records), with a single record of Rasopone ferruginea reflecting an isolated event. In contrast, $R$. ferruginea is the dominant large predator in forest patches (43 records), indicating that coffee plantations do not offer the minimal ecological requirements for this species, which remains isolated in the region's few conserved patches of forest. Similar results were found by Dias et al. (2013) in unshaded coffee in Brazil and by Philpott et al. (2006) in Mexican coffee plantations. Conversely, E. ruidum was not found in the forests studied. Endemic in Central and South America and considered an opportunistic generalist found in abundance in disturbed sites (Fernández, 1991), this species has been described as a dominant species because it is present in a variety of habitats, commonly including coffee and cocoa plantations of Central America (Lachaud, Valenzuela, Corbara, \& Dejean, 1990, Santamaria, Armbrecht, \& Lachaud, 2009). Its opportunistic behavior may allow this species to exploit places where other predatory species cannot compete, which could explain its dominance in exposed coffee plantations.

The group of specialized predatory cryptic Myrmicinae also varies according to land use: among the nine species recorded in forest patches, five were exclusive, among which the genus Strumigenys was most represented. In addition, the dominant species as measured by frequency of capture differed for each land use: Strumigenys nubila was dominant in the forest patches, Nesomyrmex asper was dominant in the SHD sites, and Cardiocondyla minutior was dominant in the SUN sites. Species of small mass recruitment tree-dwellers were abundant in the coffee plantations (SHD and SUN sites) but exhibited low frequency of capture in forests. These ants were representative in the sample, although the methodology used was aimed at ground-dwelling ants. It is possible that the scarcity of trees in the coffee plantations pressures these species to forage on the ground; in fact, a study unrelated to the current study using tuna bait to collect ants in vegetation confirmed the presence of these species in forest vegetation (Jiménez et al., 2016).

Among the fungus-growing Attini group, C. rimosus were dominant in forests and $A$. cephalotes were dominant in the SUN sites. More fungus-growing species were established in the forest patches, the majority of which have cryptic coloration, are inconspicuous, dig and build small inconspicuous nests and use decomposing organic matter to cultivate their fungi (Della Lucia, 2011). Therefore, they need appropriate conditions of moisture, temperature and organic matter, which are more easily found in forests. In contrast, A. cephalotes, or leaf-cutter ants, strip fresh plant material in large quantities as a food resource to cultivate the symbiotic fungus that feeds their large colonies (Hölldobler \& Wilson, 2010). Their nest-building and vegetation-cutting activities can drastically affect the functioning of ecosystems (Farji-Brener \& Illes, 2000, Meyer, Leal, Tabarelli, \& Wirth, 2011); their polyphagous habits make them among the most destructive pests of various crops in South America (Della Lucia, 2011, Montoya-Lerma, GiraldoEcheverri, Armbrecht, Farji-Brener, \& Calle, 2012). It has been reported that leaf-cutter ants of the genus Atta show a preference for open or sparsely vegetated locations for nesting (Vasconcelos, Vieira-Neto, Mundim, \& Bruna, 2006), suggesting a greater concentration of nests in places changed by human activity, such as unshaded coffee. In general, the species most abundant in coffee plantations are described as generalists of wide distribution, common in agro-ecosystems (Delabie et al., 2000; García et al., 2008).

An analysis of the environmental variables reveals differences among the conditions each land use has and how these differences can influence the establishment of ant communities, which is observable in the $81.34 \%$ of variability in the composition of species found. Forest patches preserve very specific conditions that make them environmentally 
different from coffee plantations; however, no statistically significant differences were found between forest patches and SHD sites in terms of the leaf litter depth, canopy cover or canopy height. This result demonstrates, on the one hand, the effect of human intervention in the forest patches studied and, on the other hand, the presence of some trees with thick trunks and well-developed canopies capable of providing a thick layer of leaf litter in some shaded coffee plantations. The presence of shade trees in the plantations promotes biodiversity in agroecosystems (Majer \& Delabie, 1999) and additional sources of income to farmers (Philpott \& Dietsch, 2003). This finding underscores the dramatic change that accompanies the removal of tree vegetation from habitats managed by humans.

\section{ACKNOWLEDGMENTS}

Receptivity and collaboration of the local community, managers and owners of the farms were fundamental to carried out this work. Authors are grateful with them. Special thanks to W. Torres for his statistical advice. To COLCIENCIAS, National Program of Basic Sciences, Code 110656933821, Contract RC. No. 0648-201, and the Universidad del Valle, Vicerrectoría de Investigaciones for funding the study. R. García thanks to the University of Quindío for the study leave.

\section{RESUMEN}

Diversidad de hormigas en tres coberturas de un paisaje cafetalero neotropical. La investigación sobre los ecosistemas de café ha recibido considerable atención en las últimas décadas. El cultivo de café ha desplazado la vegetación natural y su diversidad biológica asociada. Con el objeto de caracterizar la diversidad específica de hormigas del suelo, identificar los grupos funcionales en dos sistemas cafeteros contrastantes y relacionar esta diversidad con algunas características del hábitat, se muestrearon ocho cafetales con sombra (CCS), ocho a libre exposición (CLE) y cuatro parches de bosque en la zona cafetalera del sur de Colombia. Se trabajó en dos transectos con 12 estaciones de muestreo, en cada una se empleó búsqueda activa, trampa de caída y cernido de horajasca. Se evaluaron nueve variables del hábitat para caracterizar cada sitio y relacionar estos valores con la diversidad de hormigas. Se recolectaron 15666 individuos en 92 morfoespecies, Myrmicinae fue la subfamilia con mayor representación. La cobertura del muestreo presentó un déficit inferior al $5 \%$. Las curvas de abundancia relativas, mostraron diferencias en el ensamblaje de hormigas. Los bosques presentaron comunidades de hormigas más diversas que las de los otros usos del suelo y mayor número de especies exclusivas; el CCS mantiene el $80.3 \%$ de la diversidad de los bosques frente al $62.3 \%$ de ésta en CLE. En síntesis, la fauna de hormigas en los cafetales con sombra es más rica y equitativa que en los cultivos a libre exposición, reforzando la idea de que la implementación de la sombra favorece el establecimiento de la fauna de hormigas y, por ende, la funcionalidad ecológica.

Palabras clave: agroecosistemas de plantaciones; diversidad asociada; hormigas; cultivo de café; Colombia.

\section{REFERENCES}

Alonso, L. E., \& Agosti, D. (2000). Biodiversity studies, monitoring and ants: an overview. In D. Agosti, J. D. Majer, L. E. Alonso, \& T. R. Schultz (Eds.), Ants. Standard methods for measuring and monitoring biodiversity (pp. 1-8). Washington, D.C., USA: Smithsonian Institution Press.

Andersen, A. N. (1997). Functional groups and patterns of organization in North American ant communities: a comparison with Australia. Journal of Biogeography, 24, 433-460.

Armbrecht, I., Rivera, L., \& Perfecto, I. (2005). Reduced diversity and complexity in the leaf-litter ant assemblage of Colombian coffee plantations. Conservation Biology, 19, 897-907.

Armbrecht, I. (2003). Habitat changes in Colombian coffee farms under increasing management intensification. Endangered Species Update, 20(4-5), 163-178.

Armbrecht, I., \& Perfecto, I. (2003). Litter-twig dwelling ant species richness and predation potential within a forest fragment and neighboring coffee plantations of contrasting habitat quality in Mexico. Agriculture, Ecosystems \& Environment, 97(1), 107-115.

Cepeda-Valencia, J., Pérez -Pedraza, L., \& Fernández, F. (2014). Hormigas de hojarasca asociadas a fragmentos de bosque y cafetales de la zona cafetera de Cundinamarca, 171 registros. Retrieved from http:// ipt.sibcolombia.net/sib/resource.do? $r=$ unal-002

Chao, A., Gotelli, N. J., Hsieh, T. C., Sander, E. L., Ma, K. H., Colwell, R. K., \& Ellison, A. M. (2014). Rarefaction and extrapolation with Hill numbers: a framework for sampling and estimation in species diversity studies. Ecological Monographs, 84(1), 45-67. 
Chao, A. \& Jost, L. (2012). Coverage-based rarefaction and extrapolation: standardizing samples by completeness rather than size. Ecology, 93(12), 2533-2547.

Clarke, K. R., \& Gorley, R. N. (2006). PRIMER V6: user manual-tutorial. Plymouth, England: Plymouth Marine Laboratory.

Cumming, G., Fidler, F., \& Vaux, D. L. (2007). Error bars in experimental biology. The Journal of Cell Biology, 177(1), 7-11.

Delabie, J. H., Agosti, D., \& Nascimento, I. D. (2000). Litter ant communities of the Brazilian Atlantic rain forest region. Sampling ground-dwelling ants: case studies from the world's rain forests. Curtin University of Technology School of Environmental Biology Bulletin, (18).

Della Lucia, T. M. C. (2011). Formigas-cortadeiras: da bioecologia ao manejo. Viçosa, Brazil: Universidade Federal de Viçosa Editora.

Dias, N. D. S., Zanetti, R., Santos, M. S., Peñaflor, M. F. G. V., Broglio, S. M. F., Delabie, J. H. C., \& Scharf, I. (2013). The impact of coffee and pasture agriculture on predatory and omnivorous leaf-litter ants. Journal of Insect Science, 13(1), 29.

Dirzo, R., Young, H. S., Galetti, M., Ceballos, G., Isaac, N. J., \& Collen, B. (2014). Defaunation in the Anthropocene. Science, 345(6195), 401-406.

Espinal, L. S. (1967). Apuntes sobre ecología colombiana. Cali, Colombia: Departamento de Biología, Universidad del Valle.

Etter, A., \& van Wyngaarden, W. (2000). Patterns of landscape transformation in Colombia, with emphasis in the Andean region. Ambio: A journal of the Human Environment, 29(7), 432-439.

Farji-Brener, A. G., \& Illes, A. E. (2000). Do leaf-cutting ant nests make "bottom-up" gaps in neotropical rain forests?: a critical review of the evidence. Ecology Letters, 3, 219-227.

Federación Nacional de Cafeteros (FNC). (2010). La tierra del café. Recuperado de http://www.cafedecolombia. com/particulares/es/la_tierra_del_cafe

Federación Nacional de Cafeteros (FNC). (2011). Informe de gestión, Comité departamental de cafeteros del Cauca. Recuperado de http://www.federaciondecafeteros.org/static/files/informegestion.pdf

Fernández, F. C. (1991). Las hormigas cazadoras del género Ectatomma (Formicidae: Ponerinae) en Colombia. Caldasia, 16(79), 551-564.

Fernández, F. (2003). Introducción a las hormigas de la región neotropical. Bogotá, Colombia: Instituto de Investigación de Recursos Biológicos Alexander von Humboldt.
Fernández, F., \& Sendoya, S. (2004). List of Neotropical ants (Hymenoptera: Formicidae). Revista Biota Colombiana, 5(1), 3-93.

Ropero, M. C., \& Armbrecht, I. (2005). Depredación por hormigas sobre la broca del café Hypothenemus hampei (Curculionidae: Scolytinae) en cafetales cultivados bajo dos niveles de sombra en ColombiaAnt predation of the coffee berry borer Hypothenemus hampei (Curculionidae: Scolytinae) under two shade levels in Colombia. Manejo Integrado de Plagas y Agroecología, 76, 32-40.

García, R., Zabala, G., \& Botero, J. E. (2008). Hormigas cazadoras en paisajes cafeteros de Colombia. En E. Jiménez, F. Fernández, T. M. Arias, \& F. H. Lozano-Zambrano (Eds.), Sistemática, biogeografia y conservación de las hormigas cazadoras de Colombia (pp. 461-478). Bogotá, Colombia: Instituto de investigación de Recursos biológicos Alexander von Humboldt.

García Martínez, M. A., Martínez Tlapa, D. L., Toledo, G. R. P., Quiroz Robledo, L. N., Castaño Meneses, \& Valenzuela González, J. E. (2015). Taxonomic, species and functional group diversity of ants in a tropical anthropogenic landscape. Tropical Conservation Science, 8(4), 1017-1032.

Guhl, A. (2004). Café y cambio de paisaje en la zona cafetera colombiana entre 1970 y 1997. Cenicafé, $55(1), 29-44$

Hölldobler, B., \& Wilson, E. O. (2010). The leafcutter ants: civilization by instinct. New York, USA: WW Norton \& Company.

Jha, S., Bacon, C. M., Philpott, S. M., Ernesto Mendez, V., Läderach, P., \& Rice, R. A. (2014). Shade coffee: update on a disappearing refuge for biodiversity. BioScience, 64(5), 416-428.

Jiménez, E., García-Cárdenas, R., Escobar-Ramírez, S., Armbrecht, I. \& Montoya, J. (2016). Hormigas en cafetales con diferente intensidad de manejo en el departamento del Cauca. Recuperado de http://ipt.biodiversidad.co/valle/resource.do? $\mathrm{r}=$ hormigas-cafetales-cauca

Jiménez, E., Lozano-Zambrano, F., \& Álvarez-Saa, G. (2008). Diversidad alfa $(\alpha)$ y beta $(\beta)$ de hormigas cazadoras de suelo en tres paisajes ganaderos de los andes centrales de Colombia. En E. Jiménez, F. Fernández, T. M. Arias, \& F. H. Lozano-Zambrano (Eds.), Sistemática, biogeografia y conservación de las hormigas cazadoras de Colombia (pp. 439-459). Bogotá, Colombia: Instituto de Investigación de Recursos biológicos Alexander von Humboldt.

Jost, L. (2006). Entropy and diversity. Oikos, 113, 363-375.

Jost, L. (2007). Partitioning diversity into independent alpha and beta components. Ecology, 88, 2427-2439. 
Jost, L. (2010). The relation between evenness and diversity. Diversity, 2, 207-232.

Lachaud, J. P., Valenzuela, J., Corbara, B., \& Dejean, A. (1990). La predation chez Ectatomma ruidum: Etude de quelques parametres environnementaux. Actes des Colleques Insectes Sociaux, 6, 151-155.

Leal, I. R., Wirth, R., \& Tabarelli, M. (2014). The multiple impacts of leaf-cutting ants and their novel ecological role in human-modified neotropical forests. Biotropica, 46(5), 516-528.

Lyal, C. H., \& Weitzman, A. L. (2004). Taxonomy: exploring the impediment. Science, 305(5687), 1106-1106.

Majer, J. D., \& Delabie, J. H. C. (1999). Impact of tree isolation on arboreal and ground ant communities in cleared pasture in the Atlantic rain forest region of Bahia, Brazil. Insectes Sociaux, 46(3), 281-290.

Mehdiabadi, N. J., \& Schultz, T. R. (2010). Natural history and phylogeny of the fungus-farming ants (Hymenoptera: Formicidae: Myrmicinae: Attini). Myrmecoly News, 13, 37-55.

Mera-Velasco, Y. A., Gallego-Ropero, M. C., \& Armbrecht, I. (2010). Asociaciones entre hormigas y otros insectos en follaje de cafetales de sol y sombra, Cauca Colombia. Revista Colombiana de Entomología, 36(1), 116-126.

Meyer, S. T., Leal, I. R., Tabarelli, M., \& Wirth, R. (2011). Ecosystem engineering by leaf-cutting ants: nests of Atta cephalotes drastically alter forest structure and microclimate. Ecological Entomology, 36(1), 14-24.

Montoya-Lerma, J., Giraldo-Echeverri, C., Armbrecht, I., Farji-Brener, A., \& Calle, Z. (2012). Leaf-cutting ants revisited: towards rational management and control. International Journal of Pest Management, 58(3), 225-247.

Pacheco, R., Vasconcelos, H. L., Groc, S., Camacho, G. P., \& Frizzo, T. L. (2013). The importance of remnants of natural vegetation for maintaining ant diversity in Brazilian agricultural landscapes. Biodiversity and Conservation, 22(4), 983-997.

Perfecto, I., \& Vandermeer, J. (2002). Quality of agroecological matrix in a tropical montane landscape: ants in coffee plantations in southern Mexico. Conservation Biology, 16(1), 174-182.

Perfecto, I., \& Vandermeer, J. (2015). Coffee Agroecology: A new approach to understanding agricultural biodiversity, ecosystem services and sustainable development. New York, USA: Routledge.

Perfecto, I., \& Armbrecht, I. (2003). Technological change and biodiversity in the coffee agroecosystem of Northern Latin America. Tropical agroecosystems. Florida, USA: CRC Press.
Perfecto, I., Rice, R. A., Greenberg, R., \& Van der Voort, M. E. (1996). Shade coffee: a disappearing refuge for biodiversity. BioScience, 46(8), 598-608.

Philpott, S. M., \& Dietsch, T. (2003). Coffee and conservation: a global context and the value of farmer involvement. Conservation Biology, 17(6), 1844-1846.

Philpott, S. M., \& Foster, P. F. (2005). Nest-site limitation in coffee agroecosystems: Artificial nests maintain diversity of arboreal ants. Ecological Applications, 15(4), 1478-1485.

Philpott, S. M., \& Armbrecht, I. (2006). Biodiversity in tropical agroforests and the ecological role of ants and ant diversity in predatory function. Ecological Entomology, 31(4), 369-377.

Philpott, S., Perfecto, I., \& Vandermeer, J. (2006). Effects of management intensity and season on arboreal ant diversity and abundance in coffee agroecosystems. Arthropods Diversity and. Conservation, 1, 125-141.

Philpott, S. M., Arendt, W. J., Armbrecht, I., Bichier, P., Diestch, T. V., Gordon, C.,...Tejeda-Cruz, C. E. S. A. R. (2008). Biodiversity loss in Latin American coffee landscapes: review of the evidence on ants, birds, and trees. Conservation Biology, 22(5), 1093-1105.

Rivera, L., \& Armbrecht, I. (2005). Diversidad de tres gremios de hormigas en cafetales de sombra, de sol y bosques de Risaralda. Revista Colombiana de Entomología, 31(1), 89-96.

R Core Team. (2014). R: A language and environment for statistical computing. R Foundation for Statistical Computing. Vienna, Austria. Retrieved from http:// www.R-project.org/

Roberts, D. L., Cooper, R. J., \& Petit, L. J. (2000). Use of premontane moist forest and shade coffee agroecosystems by army ants in western Panama. Conservation Biology, 14(1), 192-199.

Saad, L. P., Souza-Campana, D. R., Bueno, O. C., \& Morini, M. S. C. (2017). Vinasse and its influence on ant (Hymenoptera: Formicidae) communities in sugarcane crops. Journal of Insect Science, 17(1), 11.

Sánchez-Clavijo, L. M., Durán, S. M., Vélez, J. G., García, R., \& Botero, J. E. (2008). Estudios regionales de biodiversidad en las zonas cafeteras de Colombia. Avances Técnicos Cenicafé, 378, 1-8.

Santamaría, C., Armbrecht, I., \& Lachaud, J. P. (2009). Nest distribution and food preferences of Ectatomma ruidum (Hymenoptera: Formicidae) in shaded and open cattle pastures of Colombia. Sociobiology, 53(2), 517.

Sinisterra, R. M., Gallego-Ropero, M. C., \& Armbrecht, I. (2016). Hormigas asociadas a nectarios extraflorales de árboles de dos especies de Inga en cafetales de Cauca, Colombia. Acta Agronómica, 65(1), 9-15. 
Silva, R. R. \& Brandão, C. R. F. (2010). Morphological patterns and community organization in leaf-litter ant assemblages. Ecological Monographs, 80, 107-124. DOI: $10.1890 / 08-1298.1$

Silvestre, R. (2000). Estrutura de comunidades de formigas do Cerrado (Doctoral dissertation). Universidad de São Paulo, Ribeirão Preto, Brazil.

Silvestre, R., Brandão, C. R. F., \& Da Silva, R. R. (2003). Grupos funcionales de hormigas: el caso de los gremios del Cerrado. En F. Fernández (Ed.), Introducción a las hormigas de la región Neotropical (pp. 101-136). Bogotá, Colombia: Instituto Humboldt Bogotá.

Urrutia-Escobar, M. X., \& Armbrecht, I. (2013). Effect of two agroecological management strategies on ant (Hymenoptera: Formicidae) diversity on coffee plantations in southwestern Colombia. Environmental Entomology, 42(2), 194-203.
Vasconcelos, H. L., Vieira-Neto, E. H., Mundim, F. M., \& Bruna, E. M. (2006). Roads alter the colonization dynamics of a keystone herbivore in Neotropical savannas. Biotropica, 38(5), 661-665.

Wild, A. L. (2007). Taxonomic revision of the ant genus Linepithema (Hymenoptera: Formicidae). Berkeley, USA: University of California Press.

Wilson, E. O. (2003). La hiperdiversidad como fenómeno real: el caso de Pheidole. In F. Fernández (Eds.), Introducción a las hormigas de la región Neotropical (pp. 363-370). Bogotá, Colombia: Instituto Humboldt.

Zabala, G. A., Arango, L. M., \& de Ulloa, P. C. (2013). Diversidad de hormigas (Hymenoptera: Formicidae) en un paisaje cafetero de Risaralda, Colombia (Hymenoptera: Formicidae) diversity in a coffee landscape of Risaralda, Colombia. Revista Colombiana de Entomología, 39(1), 141. 